\title{
On the relationship between gas emission from undermined coal-bearing stratum and the intensity of coal seam mining
}

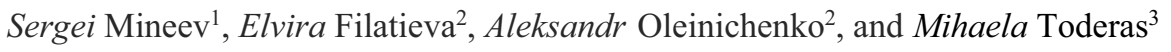 \\ ${ }^{1}$ M.S. Polyakov Institute of Geotechnical Mechanics under the National Academy of Sciences of Ukraine Dnipro, Ukraine \\ ${ }^{2}$ Volodymyr Dahl East Ukrainian National University, Severodonetsk, Ukraine \\ ${ }^{3}$ University of Petrosani, Faculty of Mines, Mining Engineering, Surveying and Constructions Department, 20 University Str., Petrosani, \\ 332006, Romania
}

\begin{abstract}
A theoretical scheme of gas release from the coalbed under production by treatment workings has been developed. The sizes of zones of different intensity of gas release from the working thickness are set according to the characteristic points of muld shift of the earth's surface. Total amount of releasing gas is determined by the area of the developed space, over which there is an intensive movement of the mined coal. The formation of this area is associated with the development of cleaning operations within the boundaries of the excavation site and the speed of movement of the treatment face. During the development of the theoretical scheme, several assumptions were made, the validity of which was verified on the basis of experimental data obtained in the conditions of four mines at fifteen excavation sites. Coal seams with coals of grades $\mathrm{G}$ and $\mathrm{A}$ were worked out by them at a depth of 300-1195 m, the capacity of coal seams was 0.90-2.20 m, cleaning works were carried out at a depth of 300-1195 m, the length of the lavas was in the range of $74 \div 270 \mathrm{~m}$. The monthly movement of the treatment faces and the amount of gas released during this period were taken into account for each excavation site. It is established that the relative gas release per unit area of the developed space remains a fairly constant value for some mining and geological conditions, if the total amount of gas is attributed to the area that determines the active movement of rocks over a moving treatment face. This allows you to use the previously obtained results of determining the categorical danger of mines by relative gas release per ton of coal production in terms of improving the forecast of gas release from the coalbed under production more efficiently.
\end{abstract}

\section{Problem statement}

In modern coal mines, the main source of gas emission is the undermined coal-bearing strata.

The relationship between the intensity of gas emission and the degree of was established several decades ago [1, 2]. The highest levels of gas emission are associated with sediments of the main roof [3] and the development of the underworked strata movement towards the earth's surface when removing waste rock. Methane emission into mine workings is possible only from the zone of underworked strata movement with a break in its continuity. In degassing wells, methane emission can also occur from lamination cavities at the contacts of rock layers with different strength properties [4].

In parallel with the influence of the underworked strata movement, the phenomenon of a decrease in the specific flow rate of methane into the stope was established with an increase in the intensity of mining of shallow coal seams [5].
The intensity of seam mining means the level of coal production and the corresponding movement of the mine face. For the safe mining of gas-bearing coal seams, it is necessary to know the mechanism of formation of methane release from the underworked coal-bearing strata. Until now, there are practically no scientific research works in which the intensity of coal seam mining (the level of coal production or the rate of mine face movement), the development of undermining and gas release from undermined sources are considered together. Research in this direction is highly relevant.

\section{Purpose, idea and research methodology}

The objective of the study is to develop a scheme for the influence of mine faces on the formation of zones of active movement of the undermined coal-bearing strata and the possible intensive emission of methane from them. Establish the factors that determine the gas emission in relation to its emission per unit area of the underworked area. 
Idea. It is assumed that the amount of emitted gas depends on both the rate of movement of the mine face $\left(v_{o y}\right)$, and the intensity of the movement of rocks above it and the degree of development of mining operations in the extraction area.

Methodology. It provides for the consideration of experimental data on methane emission in relation to the developed scheme of the influence of mine face on the formation of zones of active undermined coal-bearing strata movement and gas release from the undermined strata.

Results. The layout of the methane emission zones in the undermined coal-bearing strata was developed in accordance with the formation of a displacement trough on the earth's surface [3] and the degree of development of mining operations in the mining area (Fig. 1).

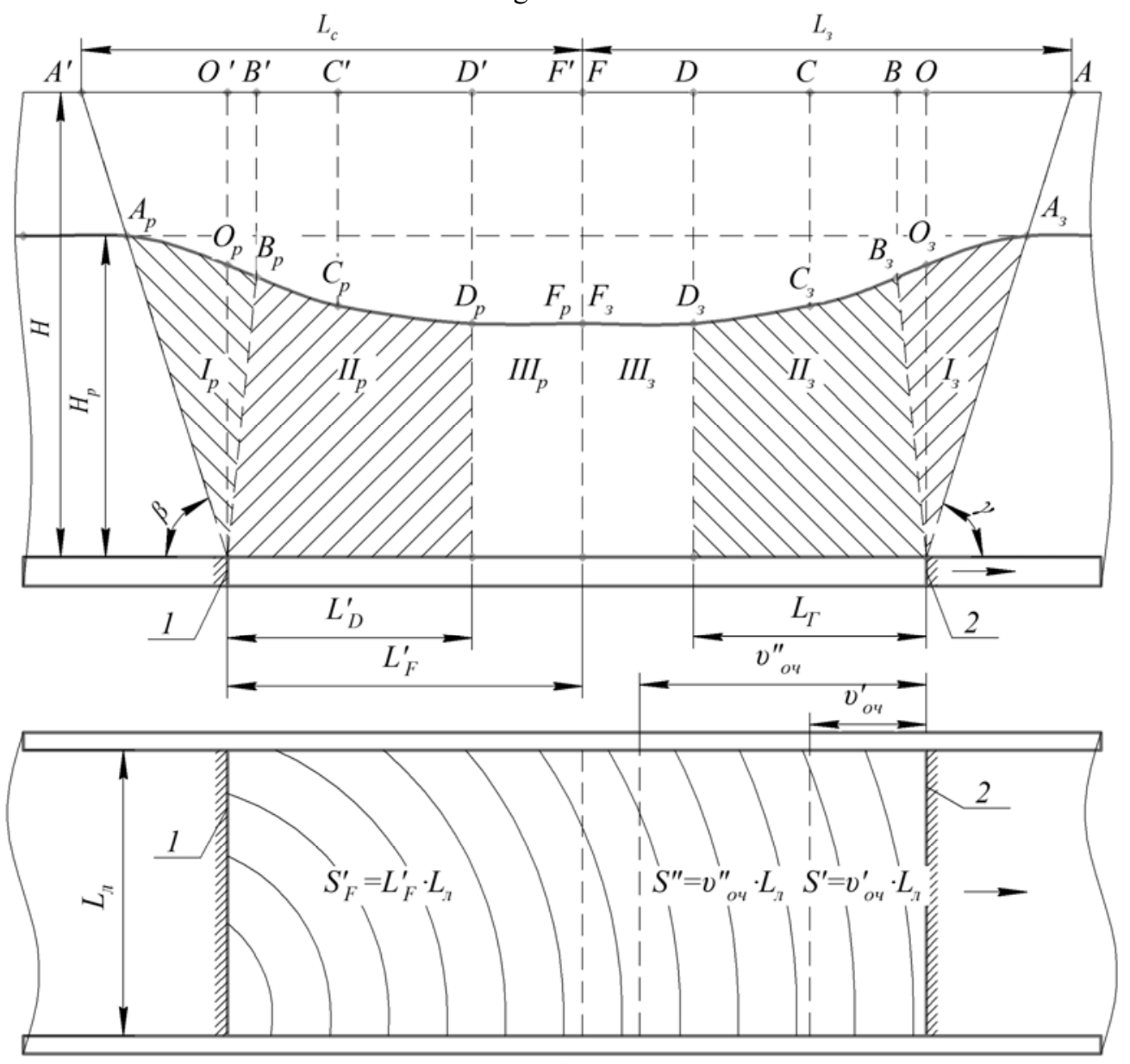

Fig. 1. Scheme of the location of gas emission zones in the undermined coal-bearing strata according to the formation of a displacement trough on the earth's surface (a) and the degree of development of cleaning work (b) in the excavation area: 1, 2- respectively, the exposed surfaces of the seam of the cut mine and the clean face; 3 - earth surface; $L_{c}, L_{\partial}$ - respectively, stationary and dynamic semitroughs; $A, O, B, C, D, F$ and $A^{\prime}, O^{\prime}, B^{\prime}, C^{\prime}, D^{\prime}, F^{\prime}$ - characteristic points of subsidence of the earth's surface of dynamic and stationary semi-troughs; $A_{p}, B_{p}, C_{p}, D_{p}, F_{p}$ and $A_{3}, B_{3}, C_{3}, D_{3}, F_{3}$ - characteristic points of subsidence of a layer of undermined rocks at the edge $\left(H_{p}\right)$ of a zone with a discontinuity, respectively above the open cut and the clean face; $H$-depth of cleaning works; $I_{3}, I I_{3}, I I I_{3}$ and $I_{p}$, $I I_{p}, I I I_{p}$ - areas of possible gas enission, respectively, above the clean face and open pit; $\beta, \gamma$ - boundary angles of influence of a working mine on the earth's surface; $L_{D}^{\prime}$ - the distance between the open pit and the clean face at which active gas emission occurs; $L_{F}^{\prime}$ - distance at which gas emission from the side of the cut furnace stops due to rock compaction; $L_{\Gamma}$ - distance from the working face, at which active gas emission occurs from the undermined coal-bearing strata above the working face; $L_{\pi}-$ longwall length; $S^{\prime}, S^{\prime \prime}-$ the goaf, respectively, when moving the working face at a distance of $v_{o u}^{\prime}$ and $v_{o u}^{\prime \prime} ; \longrightarrow$ - direction of the working face. movement.

\section{Results}

According to this scheme, a displacement trough is formed on the surface under the influence of cleaning works, which is divided into two semi-troughs. One of them, the stationary length $L_{c}$, is formed above the split mine (1). The second is a dynamic length $L_{\partial}$, it is formed as the clean face moves forward (2). These semi-troughs, according to the methods $[3,6,7]$, can be divided into separate periods of their formation using characteristic points. Section $A^{\prime} B^{\prime}$ of the semi-trough of the earth's surface (the diagram shows a segment of straight line $\left.A^{\prime} B^{\prime}\right)$ corresponds to the initial period of the earth's surface displacement under the influence of a moving clean face. The most active earth's surface displacement occurs on the curve section $B_{P} D_{P}$, and at the point $C_{P}$ the maximum subsidence rate is reached. At the point $D_{P}$, the end of the active stage occurs and the transition to damping of the processes of the earth's surface displacement occurs. At point $F$, the maximum subsidence is achieved and further 
advancement of the clean face has practically no effect on the processes of active movement of unmined rocks and the earth's surface.

Similarly, with different intensity, the undermined rocks move above the clean face in the coal-bearing strata. By analogy with the earth's surface, a subsidence semitrough is formed in it with characteristic points $A_{3}, B_{3}, C_{3}$, $D_{3}$ and $F_{3}$. Insignificant gas emission from the rock stratum is possible from zone $\mathrm{I}_{3}$, the dimensions of which are determined by the boundary angle and the position of the point $B_{3}$ in the undermined range. Point $B_{3}$ is located at a distance of $H_{p}$ from the developed formation, which defines the boundary of the displacement zone of rocks with a break in their continuity. With the removal of the stope from the cut, $H_{p}$ reaches a certain value, which remains constant as the extraction column is further worked out $[8,9,10]$. The most favorable conditions for intense gas emission appear in the zone $\left(\mathrm{II}_{3}\right)$ of active rock movement. The dimensions of this zone are determined by the section of the $B_{3}-C_{3}-D_{3}$ curve and the $H_{p}$ parameter. Separate determination of gas emission from zones $I_{3}$ and $I_{3}$ experimentally in mine conditions is practically impossible due to the technical capabilities of modern measuring equipment. Based on the gas surveys in mine workings and measurements in degassing systems, it is possible to establish the total gas emission from zones $I_{3}$ and $I_{3}$, neglecting methane emission from zone $\mathrm{III}_{3}$. The most accurate and accessible indicator characterizing the size of these zones is the area of the mined-out space $S_{\Gamma}$. It can be determined by the product of the parameter $L_{\Gamma}$ and the length of the $L_{\Omega}$ longwall. The value of the parameter $L_{\Gamma}$ is determined by the projections of points $D$ and $D_{3}$. For coal mines of Donbass, the $L_{p}$ parameter is approximately equal to 0,466 of the depth $(H)$ of mining [3]. Based on the above scheme (Fig. 1), it follows that all the gas emission from the undermined strata $\left(I_{v}\right)$ when moving the clean face can be roughly attributed to the goaf area $S_{\Gamma}=L_{\Omega} \cdot L_{\Gamma}$.

In production conditions, the value of the $L_{\Gamma}$ parameter, as a rule, does not coincide with the monthly rate of movement of the clean face. If $v_{04}<L_{\Gamma}$, when determining the specific gas emission from the ratio, this indicator will be overestimated. Gas emission in fact refers to the goaf area of $L_{\pi} \cdot L_{\Gamma}$, and it is referred, in some cases, to $S^{\prime}=v_{04}^{\prime} \cdot L_{l}$.

It is extremely rare that the $v_{04}^{\prime \prime}$ values can exceed the $L_{\Gamma}$ parameter, then $S^{\prime \prime}=v_{{ }^{\prime}}^{\prime \prime} \cdot L_{l}$ will exceed the $S_{\Gamma}=L_{\pi} \cdot L_{\Gamma}$ area and the specific gas emission per unit goaf area will be underestimated.

It can be assumed that, according to a similar scheme, gas emisiion occurs above the open cut from zones $\mathrm{I}_{3}$ and $\mathrm{II}_{3}$. Their sizes are also determined by the position of the characteristic points $A_{p}, B_{p}, C_{p}, D_{p}$ and $F_{p}$ in the underworked strata and the value of the $H_{p}$ parameter.

When the clean face is removed from the open-cut mine at a distance of $L_{D}^{\prime}$, zone $I I_{p}$ is largely degassed, since it was subjected to the most intense rock movement. Some gas emision is possible from the $I_{p}$ zone, in which rock displacements were insignificant.

When the clean face is removed from the open-cut mine at a distance of $L_{F}^{\prime}$, zones $I I I_{p}$ and $I I I_{3}$ are more degassed. The rocks in these zones, before their compaction, successively went through all stages according to the intensity of their movement and, obviously, according to the activity of gas emission from underworked sources.

In the process of developing the scheme (Fig. 1), several assumptions were made that need to be verified and confirmed by experimental results. These include the assumption of the similarity of the gas emission processes from the undermined coal-bearing strata when the clean faces are removed from the split furnaces in the initial period of the excavation sections operation at a distance of $L_{D}^{\prime}$ (with the settlement of the main roof in zone $I I_{p}$ ) and methane emission above the clean face, determined by the boundaries of zone $I_{3}$ and the goaf area $S_{\Gamma}$, calculated using the parameter $L_{\Gamma}$.

The analysis involved the results of the cleaning works development observations and gas emission at fifteen excavation areas of four mines. For these sites, in advance, considering the depth $(H)$ of the cleaning works, the $L_{\Gamma}$ parameter was determined [3]. For the conditions of the A.F. Zasyadko mine [11] (16th eastern longwall of the $m_{3}$ seam) for a depth of $H=1195 \mathrm{~m}$, the value of $L_{\Gamma}$ is $547 \mathrm{~m}$.

In the conditions of the 'Sukhodolskaya Vostochnaya' mine, during the operation of the 12th bis and 24th eastern longwall of the $i_{3}$ seam, the depths were 965 and $1016 \mathrm{~m}$ respectively, and they corresponded to $L_{\Gamma}$ values of 450 and $474 \mathrm{~m}$. For the D.F. Melnikov mine, the extraction area of the 1 st northern longwall of the $\ell_{6}$ seam was mined at a depth of $852 \mathrm{~m}$, for which the parameter was $397 \mathrm{~m}$. Mine in the name of the "Izvestia" newspaper mined an anthracite layer $\ell_{2}^{b}$ at a depth of $300 \mathrm{~m}$, and the calculated value of the $L_{\Gamma}$ parameter was $140 \mathrm{~m}$.

For each excavation site, monthly movements of the clean faces were pre-established and the amount of gas emission during this period was determined experimentally. After that, the movement of the clean faces $\left(L_{o y}\right)$ was sequentially selected for a certain period (one or several months), starting from the moment of longwall operation in such a way that $L_{о ч} \approx L_{\Gamma}$. Then, for the selected values of $L_{o 4}$, the goaf areas $S_{\Gamma}=L_{o 4} \cdot L_{\Gamma}$ were found, which corresponded to gas emission when the clean faces moved to a distance of $L_{\text {оч }}$. We also took into account the period of longwall operation $(t)$ when moving the faces to a distance of $L_{o 4}$, the average gas emission per month and the specific methane emission $\frac{I_{v}}{S}$ per $\mathrm{m}^{2}$ of the goaf area when moving the clean faces at a distance of $L_{\text {o }}$. This data is summarized in Table 1.

When the clean faces move in the initial period of exploitation of the extraction areas at a distance $L_{o u} \approx L_{\Gamma}=L_{D}^{\prime}$ (Fig. 1, Table 1), in most cases, the indicators of the amount of gas $\left(\mathrm{I}_{v}\right)$, its average amount $\left(\bar{I}_{1}\right)$ emitted in one month, as well as the specific gas emission from units of the goaf area $\left(\frac{I_{v}}{S_{\Gamma}}\right)$ were less in comparison with their subsequent values when moving the clean faces at a distance of $L_{о ч}$. This is explained by the fact that intense gas emission from the undermined coal-bearing strata does not begin immediately after the 
introduction of the longwalls into exploitation, but occurs after the main roof has settled.

For example, in the conditions of the "Izvestia" mine, the sediment of the main roof occurred when removing clean face from cut workings at a distance of $80 \div 120 \mathrm{~m}$ [3]. At the same time, the peak values of methane emission when moving the clean faces on the $L_{D}^{\prime}$ section (Fig. 1, a), located closer to the open-cut working, were slightly higher than the gas emissions during their subsequent moves by the value of $L_{\Gamma}$. The total amount of gas $I_{v}$ emitted during the passage of the longwall sections $L_{\Gamma}$ of the extraction pillars located far from the split furnaces, as a rule, exceeded this indicator during the operation of longwalls near the split workings.

Table 1. Information about the operating conditions of longwalls in zones of active rock movement and intense gas emission from undermined sources $\left(L_{\Gamma}\right)$.

\begin{tabular}{|c|c|c|c|c|c|c|c|c|}
\hline Lawa & $\begin{array}{l}\text { Face } \\
\text { length, } \\
L_{n}, \mathrm{~m}\end{array}$ & $\begin{array}{c}\text { Estimated size of } \\
\text { the gas emission } \\
\text { zone, } L_{\Gamma}, \mathrm{m}\end{array}$ & $\begin{array}{l}\text { Clean face } \\
\text { movement, } \\
L_{04} \approx L_{\Gamma}, \mathrm{m}\end{array}$ & $\begin{array}{c}\text { Goaf area, } \\
S_{I}=L_{o y} \cdot L_{l}, \mathrm{~m}^{2}\end{array}$ & \begin{tabular}{|c|} 
Gas \\
emission, $I_{v}$, \\
mil. $\mathrm{m}^{3}$
\end{tabular} & \begin{tabular}{|c|} 
Longwall \\
life, $t$ \\
month.
\end{tabular} & $\begin{array}{l}\text { Average gas emission } \\
\text { per month, } \bar{I}_{1}, \text { mil. } \mathrm{m}^{3}\end{array}$ & $\begin{array}{c}\frac{I_{v}}{S_{I}} \\
\mathrm{~m}^{3} / \mathrm{m}^{2} \\
\end{array}$ \\
\hline 1 & 2 & 3 & 4 & 5 & 6 & 7 & 8 & 9 \\
\hline \multicolumn{9}{|c|}{ A.F. Zasyadko mine [11] } \\
\hline \multirow{3}{*}{$\begin{array}{l}16 \text { th } \\
\text { eastern }\end{array}$} & \multirow{3}{*}{270} & \multirow{3}{*}{547} & $552 *$ & 149040 & 15,7 & 5 & 3,1 & 105,3 \\
\hline & & & 540 & 145800 & 18,9 & 5 & 3,8 & 129,6 \\
\hline & & & 541 & 146070 & 18,0 & 4 & 4,5 & 123,2 \\
\hline \multicolumn{9}{|c|}{ 'Sukhodolskaya - Vostochnaya' mine } \\
\hline \multirow{2}{*}{$\begin{array}{l}\text { 12th bis } \\
\text { eastern }\end{array}$} & \multirow{2}{*}{240} & \multirow{2}{*}{450} & $448^{*}$ & 107520 & 14,3 & 16 & 0,9 & 133,0 \\
\hline & & & 431 & 103440 & 20,5 & 20 & 1,0 & 198,2 \\
\hline \multirow{3}{*}{$\begin{array}{c}\text { 24th } \\
\text { eastern }\end{array}$} & \multirow{3}{*}{240} & \multirow{3}{*}{474} & $455^{*}$ & 109200 & 15,7 & 7 & 2,2 & 143,8 \\
\hline & & & 454 & 108960 & 24,8 & 11 & 2,3 & 227,6 \\
\hline & & & 203 & 48720 & 16,0 & 9 & 1,8 & 328,4 \\
\hline \multicolumn{9}{|c|}{ D.F. Melnikov mine } \\
\hline \multirow{4}{*}{$\begin{array}{c}1 \text { st } \\
\text { northern }\end{array}$} & \multirow{4}{*}{220} & \multirow{4}{*}{397} & $408^{*}$ & 89760 & 2,8 & 12 & 0,2 & 31,2 \\
\hline & & & 409 & 89980 & 2,7 & 9 & 0,3 & 30,0 \\
\hline & & & 392 & 86240 & 5,3 & 30 & 0,2 & 61,5 \\
\hline & & & 0 & 0 & 0,5 & 8 & 0,06 & 5,7 \\
\hline \multicolumn{9}{|c|}{ Newspaper "Izvestia" mine [12] } \\
\hline \multirow{5}{*}{$\begin{array}{c}1 \mathrm{st} \\
\text { western }\end{array}$} & \multirow{2}{*}{185} & \multirow{5}{*}{140} & $143^{*}$ & 26455 & 0,9 & 4 & 0,2 & 34,0 \\
\hline & & & 139 & 25715 & 1,3 & 5 & 0,3 & 50,6 \\
\hline & 157 & & 132 & 20724 & 1,7 & 4 & 0,4 & 62,4 \\
\hline & 115 & & 131 & 15065 & 1,8 & 6 & 0,3 & 119,5 \\
\hline & 111 & & 156 & 17316 & 0,4 & 4 & 0,1 & 23,1 \\
\hline \multirow{3}{*}{$\begin{array}{c}\text { 1st bis } \\
\text { western }\end{array}$} & 74 & & $113^{*}$ & 8362 & 0,2 & 4 & 0,05 & 23,9 \\
\hline & 84 & 140 & 152 & 12768 & 0,5 & 3 & 0,2 & 39,2 \\
\hline & 94 & & 115 & 10810 & 0,4 & 8 & 0,05 & 37,0 \\
\hline & & & $129 *$ & 25800 & 0,9 & 2 & 0,5 & 34,9 \\
\hline & & & 107 & 21400 & 2,0 & 1 & 2,0 & 93,5 \\
\hline & & & 143 & 28600 & 3,1 & 2 & 1,6 & 108,4 \\
\hline 2nd & 200 & 140 & 86 & 17200 & 1,4 & 1 & 1,4 & 81,4 \\
\hline & & & 133 & 26600 & 1,6 & 1 & 1,6 & 60,2 \\
\hline & & & 139 & 27800 & 1,8 & 1 & 1,8 & 64,7 \\
\hline & & & 127 & 25400 & 1,4 & 1 & 1,4 & 55,1 \\
\hline 2nd bis & 185 & 140 & $123^{*}$ & 22755 & 1,4 & 4 & 0,4 & 61,5 \\
\hline western & 180 & 140 & 156 & 28860 & 3,1 & 10 & 0,3 & 107,4 \\
\hline & & & $141^{*}$ & 30315 & 1,6 & 2 & 0,8 & 52,8 \\
\hline & & & 91 & 19565 & 1,4 & 1 & 1,4 & 71,6 \\
\hline 3 th & 215 & 140 & 112 & 24080 & 1,6 & 1 & 1,6 & 64,4 \\
\hline western & 215 & 140 & 131 & 28165 & 1,6 & 1 & 1,6 & 56,8 \\
\hline & & & 153 & 32895 & 2,9 & 2 & 1,5 & 80,2 \\
\hline & & & 132 & 28380 & 1,4 & 1 & 1,4 & 49,3 \\
\hline & & & 194* & 40740 & 0,7 & 2 & 0,4 & 17,2 \\
\hline & & & 112 & 23520 & 3,3 & 2 & 1,7 & 140,3 \\
\hline & & & 150 & 31500 & 2,2 & 2 & 1,1 & 69,8 \\
\hline 4th & 210 & 140 & 163 & 34230 & 2,0 & 2 & 1,0 & 58,4 \\
\hline western & 210 & 140 & 140 & 29400 & 1,5 & 1 & 1,5 & 51,0 \\
\hline & & & 128 & 26880 & 2,1 & 1 & 2,1 & 78,4 \\
\hline & & & 154 & 32340 & 1,5 & 1 & 1,5 & 46,4 \\
\hline & & & 153 & 32130 & 1,2 & 1 & 1,2 & 37,3 \\
\hline
\end{tabular}

* Note - removal of clean faces from cut workings at a distance of $L_{o u}$ in the period before the settlement of the main roof. 
Such a ratio of indicators for gas emission in the areas $L_{D}^{\prime}$ and $L_{\Gamma}$ indicates a different course of the processes of rock displacement and gas emission when clean faces are located in different parts of the extraction pillars.

We examined in more detail the cases when mining pillars in the areas $L_{D}^{\prime}$ and $L_{\Gamma}$, when the indicators $I_{v}, \bar{I}_{1}$ and $\frac{I_{v}}{S_{\Gamma}}$ were quantitatively close to each other.

The D.F. Melnikov mine, during the operation of the 1 st northern longwall of the $\ell_{6}$ seam, the section of the pillar $L_{D}^{\prime}=L_{o u}=408 \mathrm{~m}$ near the split furnace was worked out for twelve months, and the subsequent section $L_{\Gamma}=$ $409 \mathrm{~m}$ after the settlement of the main roof - nine months (Table 1). During these periods, approximately the same amount of methane was emitted, respectively 2,8 and 2,7 mil $\mathrm{m}^{3}$. In this case, with approximately the same areas of undermined stratum (89760 and $89980 \mathrm{~m}^{2}$ ), practically the same amount of gas was emitted over different periods of time when a part of the extraction pillar was worked out on segments $L_{D}^{\prime}$ and $L_{\Gamma}$. This indicates that the amount of methane emitted from the zone of active movement of underworked rocks depends on the time of degassing of the coal-bearing strata. The influence of the time factor on all indicators of gas emission $I_{v}, \bar{I}_{1}$ и $\left.\frac{I_{v}}{S_{\Gamma}}\right)$ ) is confirmed by the experimental results obtained during the refinement of the extraction pillar of the 1st northern longwall with a length of $392 \mathrm{~m}$ for thirty months. During this period, 5,3 mil $\mathrm{m}^{3}$ of gas was released, because of which the $\frac{I_{v}}{S_{\Gamma}}$ indicator also increased from 30,0 to $61,5 \mathrm{~m}^{3} / \mathrm{m}^{2}$ of methane (Table 1). The amount of methane emitted per month remained practically unchanged. After stopping the clean face $\left(S_{\Gamma}=0\right), 0,5 \mathrm{mil} \mathrm{m}^{3}$ of methane was emitted over eight months. The $\frac{I_{v}}{S_{\Gamma}}$ indicator must be determined according to the scheme (Fig. 1) from the $\frac{I_{v}}{L_{\Gamma} \cdot L_{Л}}=$ $\frac{0,5 \cdot 10^{-6}}{397 \cdot 220}=5,7 \mathrm{~m}^{3} / \mathrm{m}^{2}$ ratio. After stopping the clean face, its movement is absent, which caused a decrease in the specific gas emission per unit of goaf area from 61,5 to $5,7 \mathrm{~m}^{3} / \mathrm{m}^{2}$. In this case, if the amount of emitted gas is related to the area corresponding to the monthly movement of the clean face $\left(S_{v}=0\right)$, then the $\frac{I_{v}}{S_{v}}$ indicator tends to infinity and it has no practical value. A similar mistake is made by the methodology of regulatory framework when determining the hazardousness of mines, when the amount of emitted gas is attributed to coal production per month. In its absence, the gas content of the mine seemingly tends to infinity. The absolute gas emission when the clean face is stopped depends on the the location of sources in the undermined coal-bearing strata, which are no longer associated with coal mining $[13,14]$.

On the site of the 8 th western longwall of the $\ell_{2}^{\mathrm{B}}$ seam of the "Izvestia" mine part of the extraction column $L_{D}^{\prime}=L_{o \psi}=151 \mathrm{~m}$ was worked out for three months, and the next $-L_{\Gamma}=131 \mathrm{~m}$ for one month. During the exploitation of the mining area, 1,4 and 1,2 mil $\mathrm{m}^{3}$ of methane was emitted in the corresponding periods. Indicators $\bar{I}_{1}$ and $\frac{I_{v}}{S_{\Gamma}}$ in the corresponding periods were equal to 0,5 and 1,2 million $\mathrm{m} 3$ and 43,1 and $42,6 \mathrm{~m}^{3} / \mathrm{m}^{2}$. In this case, with the same $\frac{I_{v}}{S_{\Gamma}}$ indicator, the average amount of gas emitted in one month significantly differed. Such a ratio of parameters in this case can be explained by the incomplete development of rock displacement processes at the initial stage of seam development at $L_{04}=151 \mathrm{~m}$. After stopping the longwall, $0,5 \mathrm{mil} \mathrm{m}^{3}$ of gas was emitted in two months. For this case, $\frac{I_{v}}{S_{\Gamma}}=\frac{0,5 \cdot 10^{-6}}{140 \cdot 215}=16,6 \mathrm{~m}^{3} / \mathrm{m}^{2}$. This indicates a decrease in the specific gas emission per unit of goat area in the absence of coal mining for a certain period.

After stopping the 9th western longwall, 0,3 million $\mathrm{m}^{3}$ of methane was emitted in four months, and the specific gas emission during this period was $8,6 \mathrm{~m}^{3} / \mathrm{m}^{2}$. This confirms the validity of the fact that when calculating the specific gas emission per unit of goaf area, the amount of emitted gas $I_{v}$ must be related to the $S_{\Gamma}$ area that determines the active zone of rock displacement.

If the rate of clean face movement $\left(v_{\mathrm{ou}}\right)$ is approximately equal to the calculated value of the size of the zone of active displacement of rocks $\left(L_{\Gamma}\right)$ (Fig. 1), then it can be assumed that the values of specific methane emission per unit goaf area $\left(\frac{I_{v}}{S_{v}}\right.$ and $\left.\frac{I_{v}}{S_{\Gamma}}\right)$ will slightly differ from each other. The closeness of the $\frac{I_{v}}{S_{v}}$ and $\frac{I_{v}}{S_{\Gamma}}$ parameters in this case also indirectly indicates the reliability of determining $L_{\Gamma}$ by a calculation method.

Of the considered excavation areas, working out different seams, only in the conditions of the "Izvestia" mine for individual mining areas, in some cases, the speed of clean faces $\left(v_{o y}\right)$ was close to the indicator $L_{\Gamma}=140 \mathrm{~m}$. The $L_{\Gamma}$ determination accuracy is about $20 \%$. In this case, the $L_{\Gamma}$ value is $140 \div 28 \mathrm{~m}$ and should be in the range $112 \div 168 \mathrm{~m}$.

For six excavation areas, where there were cases of approximate equality $L_{\Gamma} \approx v_{\text {оч }}$, we made samples according to the rate of clean faces movement in the indicated interval $(112 \div 168 \mathrm{~m})$ and the corresponding amount of released gas $\left(I_{v_{\text {ou }}}\right)$ and area $\left(S_{v_{\text {ou }}}\right.$ and $\left.S_{\Gamma}\right)$ of worked-out spaces (Table 2). The graphs of the experimentally determined $\frac{I_{v_{o u}}}{S_{\Gamma}}$ and $\frac{I_{v_{0 u}}}{S} v_{o u}$ values practically coincided with the bisector (1) of the coordinate grid (Fig. 2).

This is evidenced by the closeness of the regression coefficient to unity of the averaging straight line (2) and the high value of the correlation coefficient $(r=0,97)$. The established facts indicate that in order to reliably determine the specific gas emission from a unit area of the goaf, it is necessary to take into account the zones of active movement of underworked rocks.

\section{Conclusions}

Conducted theoretical and experimental studies of gas emission from the undermined coal-bearing stratum by workings made it possible to draw the following conclusions:

- the developed theoretical scheme for the joint formation of zones of the undermined coal-bearing stratum active movement and intense gas emission made it possible, on the basis of experimental data, to establish 
a part of the goaf area, which determines the amount of methane emitted from the sources;

Table 2. Information on gas emission at the rates of clean faces $\left(v_{o u}\right)$ is close to the size of the $L_{\Gamma}$ zone of active movement of rocks in the conditions of the "Izvestia" mine.

\begin{tabular}{|c|c|c|c|c|c|c|c|c|c|}
\hline \multirow[t]{2}{*}{ Lawa } & \multirow{2}{*}{$\begin{array}{c}\text { Face } \\
\text { length, } L_{\pi}, \\
\mathrm{m}\end{array}$} & \multirow{2}{*}{$\begin{array}{l}\text { Speed of face } \\
\text { movement, } v_{\text {oч }} \text {, } \\
\text { m/month }\end{array}$} & \multirow{2}{*}{$\begin{array}{c}\text { Average methane } \\
\text { amount in a seam, } \\
\mathrm{m}^{3} / \text { t.m.r. }\end{array}$} & \multirow{2}{*}{$\begin{array}{l}\text { Amount of emitted } \\
\text { gas, } I_{v} \text {, thousand. } \\
\mathrm{m}^{3}\end{array}$} & \multicolumn{2}{|c|}{$\begin{array}{c}\text { Goaf area, } \\
\mathrm{m}^{2}\end{array}$} & \multicolumn{2}{|c|}{$\begin{array}{c}\text { Gas emitted from } \\
1 \mathrm{~m}^{2} \text { of goaf, } \\
\mathrm{m}^{3} / \mathrm{m}^{2}\end{array}$} & \multirow{2}{*}{$\begin{array}{c}\text { Observation } \\
\text { date }\end{array}$} \\
\hline & & & & & $S_{v_{v^{4}}}$ & $S_{\Gamma}$ & $\frac{I_{v}}{S_{v_{o y}}}$ & $\frac{I_{v}}{S_{\Gamma}}$ & \\
\hline 1 & 2 & 3 & 4 & 5 & 6 & 7 & 8 & 9 & 10 \\
\hline \multirow{4}{*}{$\begin{array}{c}\text { 2nd } \\
\text { western }\end{array}$} & \multirow{4}{*}{200} & 133 & 20,4 & 1589,2 & 26600 & 28000 & 59,7 & 56,8 & III 1979 \\
\hline & & 139 & 18,6 & 1766,9 & 27800 & 28000 & 63,6 & 63,1 & IV 1979 \\
\hline & & 127 & 15,8 & 1415,1 & 25400 & 28000 & 55,7 & 50,5 & V 1979 \\
\hline & & 132 & 12,3 & 933,1 & 26400 & 28000 & 35,3 & 33,3 & VI 1979 \\
\hline \multirow{7}{*}{$\begin{array}{c}\text { 3th } \\
\text { western }\end{array}$} & \multirow{7}{*}{215} & 112 & 26,5 & 1607,0 & 24080 & 30100 & 66,7 & 53,4 & XI 1979 \\
\hline & & 131 & 26,5 & 1584,7 & 28165 & 30100 & 56,3 & 52,6 & XII 1979 \\
\hline & & 132 & 25,8 & 1391,0 & 28380 & 30100 & 49,0 & 46,2 & IV 1980 \\
\hline & & 144 & 24,8 & 866,0 & 30960 & 30100 & 28,0 & 29,4 & V 1980 \\
\hline & & 130 & 22,4 & 738,7 & 27950 & 30100 & 26,4 & 24,5 & VI 1980 \\
\hline & & 134 & 20,2 & 915,1 & 28810 & 30100 & 31,8 & 30,4 & VII 1980 \\
\hline & & 116 & 15,8 & 709,8 & 24940 & 30100 & 28,5 & 23,6 & VIII 1980 \\
\hline \multirow{6}{*}{$\begin{array}{c}4 \text { th } \\
\text { western }\end{array}$} & \multirow{6}{*}{210} & 123 & 28,1 & 738,7 & 25830 & 29400 & 28,6 & 25,1 & XI 1980 \\
\hline & & 140 & 29,3 & 1481,8 & 29400 & 29400 & 50,4 & 50,4 & VI 1981 \\
\hline & & 128 & 28,9 & 2129,3 & 26880 & 29400 & 79,2 & 72,4 & VII 1981 \\
\hline & & 154 & 28,4 & 1473,1 & 32340 & 29400 & 45,6 & 50,1 & VIII 1981 \\
\hline & & 153 & 27,1 & 1213,9 & 32130 & 29400 & 37,8 & 41,3 & IX 1981 \\
\hline & & 128 & 24,4 & 589,2 & 26880 & 29400 & 21,9 & 20,0 & X 1981 \\
\hline \multirow{2}{*}{$\begin{array}{c}5 \text { th } \\
\text { western }\end{array}$} & \multirow{2}{*}{216} & 147 & 31,3 & 1330,3 & 31752 & 30240 & 41,9 & 44,0 & VIII 1982 \\
\hline & & 149 & 31,0 & 334,8 & 32184 & \begin{tabular}{|l|}
30240 \\
\end{tabular} & 10,4 & 7,5 & IX 1982 \\
\hline \multirow{2}{*}{$\begin{array}{c}7 \text { th } \\
\text { western }\end{array}$} & \multirow{2}{*}{230} & 118 & 34,8 & 1767,7 & 27140 & 32200 & 65,1 & 54,9 & VIII 1983 \\
\hline & & 116 & 34,3 & 1412,6 & 26680 & 32200 & 52,9 & 43,9 & IX 1983 \\
\hline \multirow{2}{*}{$\begin{array}{c}\text { 8th } \\
\text { western }\end{array}$} & \multirow{2}{*}{215} & 131 & 35,0 & 1160,6 & 28165 & \begin{tabular}{|l|}
30100 \\
\end{tabular} & 41,2 & 38,6 & VIII 1984 \\
\hline & & 130 & 34,7 & 1032,4 & 27950 & 30100 & 37,0 & 34,3 & IX 1984 \\
\hline
\end{tabular}

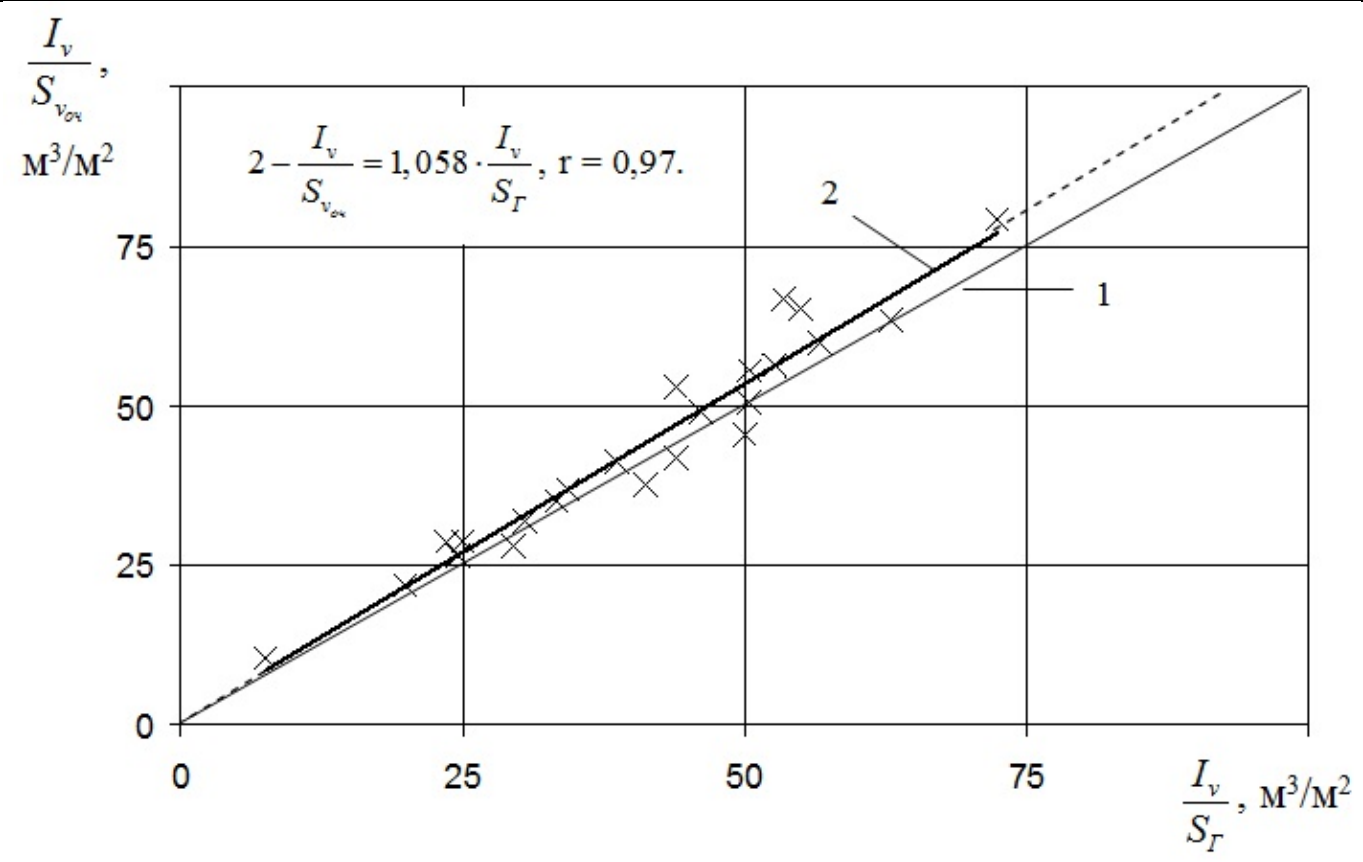

Fig. 2. Graph of the ratio of specific gas emissions per unit goaf, determined, respectively, by the monthly movement of the clean faces $\left(\frac{I_{v}}{S_{v_{\text {оч }}}}\right)$ and the zone of active rock movement $\left(\frac{I_{v}}{S_{\Gamma}}\right)$ during mining of the $\ell_{2}^{b}$ seam by the "Izvestia" mine: 1 - grid bisector; 2 - averaging straight line; $\times$ - experimental data; $r$ - correlation coefficient. 
- in the conditions of four mines at 15 excavation areas, the distinctive features of specific gas emission (per unit of goaf area) have been established, which are determined by the development of cleaning work and the speed of moving the clean face;

- the main factors that determine the specific gas emission are the area of the goaf, which affects the active stages of rock movement and the time period required for the formation of this goaf area;

- the obtained scientific conclusions make it possible to more effectively use the results of establishing the category of gas hazards in mines in terms of relative gas emission per ton of coal production in terms of improving the forecast of gas emission from the undermined coalbearing stratum.

\section{References}

1. A.M. Morev, I.M. Evseev, Degazaciya sblizhennyh plastov (Nedra, Moscow, 1975)

2. A.T. Ajruni, Teoriya i praktika bor'by s rudnichnymi gazami na bol'shih glubinah (Nedra, Moscow, 1981)

3. M.V. Filatiev, N.I. Antoshchenko, A.I. Dubovik, Geomekhanicheskie processy sdvizheniya podrabotannyh porod $i$ obosnovanie metodiki prognoza gazovydeleniya $v$ ugol'nyh shahtah (Lisichansk, DonSTU, 2017)

4. L.V. Savenko, M.I. Ozerkin, Degazaciya sputnikov ugol'nyh plastov (Kiev, GITL USSR, 1963)

5. M. A. Il'yashov, S. I. Skipochka, A. V. Agafonov et al., Yavlenie snizheniya udel'nogo debita metana $v$ ochistnuyu vyrabotku iz ugleporodnogo massiva pri povyshenii intensivnosti otrabotki pologih ugol'nyh plastov (Otkrytie №411, NA-515, Prioritet, 2017, 2019)

6. S.B. Kulibaba, vol. of Ukr NDMI NAN Ukraïni. 9, 173-179 (2011)

7. Yu.N. Gavrilenko, Ugol' Ukrainy. 6, 45-49 (2011)

8. M.I. Lobkov, avtoreferat disertaciï, Rozvitok naukovih osnov prognozu obvalennya porid pokrivli pri vijmanni lavoyu pologogo plasta (Donetsk, 2012)

9. N. Shvaher, T. Komisarenko, S. Chukharev, S. Panova, E3S Web of Conf. 123 (2019). https://doi.org/10.1051/e3sconf/201912301043

10. S. Pysmennyi, M. Fedko, N. Shvaher, S. Chukharev, E3S Web of Conf. 201 (2020). https://doi.org/10.1051/e3sconf/202020101022.

11. V.V. Bokij, O.I. Kasimov, Ugol' Ukrainy. 5, 17-21 (2005)

12. N.I. Antoshchenko et al., Bezopasnaya otrabotka gazonosnyh ugol'nyh plastov s uchetom geomekhanicheskih processov sdvizheniya podrabotannyh porod (Alchevsk, DonSTU, 2014)

13. M. Filatiev, E. Filatieva, M. Antoshchenko, E3S Web of Conferences $\quad 60$ (2018) https://doi.org/10.1051/e3sconf/20186000019

14. M. Filatiev, Naukovyi Visnyk Natsionalnoho Hirnychoho Universytetu 1, 27 - 33 (2017). 